\title{
EVALUASI IMPLEMENTASI TQM PADA SDN KARANGREJEK II DAN SD MUHAMMADIYAH AL MUJAHIDIN WONOSARI GUNUNGKIDUL
}

\author{
Eko Pramono, Lantip Diat Prasojo \\ SDN Soka Wonosari, Universitas Negeri Yogyakarta \\ 3kopramono@gmail.com, lantip1975@gmail.com
}

\begin{abstract}
Abstrak
Penelitian ini bertujuan mengetahui: (1) seberapa besar tingkat implementasi TQM, (2) perbandingan implementasi, (3) aspek-aspek yang perlu mendapatkan perbaikan untuk ditingkatkan. Penelitian evaluasi dengan model descrepancy. Instrumen pengumpul data berupa angket jawaban skala 2 terdiri atas 69 butir. Teknik analisis data menggunakan teknik persentase. Hasil penelitian menunjukkan bahwa: (1) implementasi TQM di SD Negeri Karangrejek II rata-rata sebesar $87,73 \%$, aspek-aspek yang mendekati standar: mutu pembelajaran, organisasi terbalik, perubahan kultur, kolega sebagai pelanggan, profesionalisme, dan pemasaran internal. Implementasi TQM di SD Muhammadiyah Al Mujahidin rata-rata sebesar 94,42\%. Aspek-aspek yang mendekati standar: organisasi terbalik, mutu pembelajaran, perubahan kultur, profesionalisme, kaizen dan menjaga hubungan dengan pelanggan. (2) Perbandingan implementasi TQM sebagai berikut: aspek mutu pembelajaran, organisasi terbalik dan perubahan kultur merupakan aspek dengan rata-rata tertinggi di SD Karangrejek II, sedangkan di SD Muhammadiyah Al Mujahidin: aspek organisasi terbalik, mutu pembelajaran, dan perubahan kultur. (3) Aspek yang perlu mendapatkan perbaikan di kedua sekolah adalah perbaikan terus-menerus.
\end{abstract}

Kata kunci: evaluasi, Total Quality Management (TQM)

\section{EVALUATION ON THE IMPLEMENTATION OF TQM SDN KARANGREJEK II AND SD MUHAMMADIYAH AL MUJAHIDIN WONOSARI GUNUNGKIDUL}

\begin{abstract}
This study aimed to determine : (1) the extent of the implementation TQM, (2) a comparison of the implementation, (3) aspects that need improvement for enhanced. This study is an evaluation of descrepancy models. The data were collected by means of instruments such as questionnaires, with a response two-scale consisting of 69 items. The data were analysed using the percentage technique of data analysis techniques. The results of this study indicate that: (1) the implementation of TQM in the Elementary School II Karangrejek has an average of $87.73 \%$, whith aspects that are close to the standard are: the quality of learning, the upside-down organization, culture change, colleagues as customers, professionalism and internal marketing. The implementation of TQM in Elementary School of Muhammadiyah Al Mujahidin has an average of $94.42 \%$. The aspects that are close to the standard are: the upside-down organization, the quality of learning, culture change, professionalism, kaizen and keeping close to the costumers. (2) The comparison of the implementation of TQM is as follows: the quality aspect of learning, organizational culture change, upside-down organization are aspect with the highest average in elementary school Karangrejek II, while in elementary school of Muhammadiyah Al Mujahidin, upside-down organizational aspects, the quality of learning, and culture change. (3) The aspect that need improvement for enhanced in both schools is continuous improvement.
\end{abstract}

Keywords: evaluation, Total Quality Management (TQM) 



\section{Pendahuluan}

Peningkatan kualitas sumber daya manusia merupakan prasyarat mutlak untuk mencapai tujuan pembangunan. Salah satu cara untuk meningkatkan kualitas sumber daya manusia adalah pendidikan. Sumber daya manusia yang berkompeten yang dihasilkan oleh pendidikan akan menjadi sumber pembangunan, demikian pula sebaliknya apabila pendidikan tidak mampu menghasilkan sumber daya manusia yang kompeten akan menjadi beban bagi pembangunan. Sebagai penentu keberhasilan pembangunan, kualitas SDM harus ditingkatkan melalui berbagai program pendidikan yang dilaksanakan secara sistematis dan terarah berdasarkan kepentingan yang mengacu pada kemajuan ilmu pengetahuan dan teknologi (iptek) dan dilandasi oleh keimanan dan ketakwaan (Imtak).

Indikator keberhasilan pembangunan SDM nampak pada mutu pendidikan bangsa tersebut. Pendidikan yang bermutu akan menghasilkan SDM yang unggul. Masalah mutu pendidikan harus menjadi perhatian serius pemerintah sebagai pembuat kebijakan, lembaga pendidikan sebagai pelaksana, dan masyarakat sebagai pengguna pendidikan. Harapannya apabila mutu pendidikan bagus, maka bagus pula kualitas peradaban bangsa tersebut.

Mutu pendidikan merupakan salah satu tolok ukur keberhasilan sebuah proses pendidikan yang bisa dirasakan oleh masyarakat mulai dari input (masukan), proses pendidikan yang terjadi, hingga output (produk keluaran) dari sebuah proses pendidikan. Mutu pendidikan dapat diartikan sebagai kemampuan organisasi pendidikan dalam pengelolaan secara operasional, efektif, dan efisien terhadap semua komponen yang berkaitan dengan dunia pendidikan, sehingga menghasilkan nilai tambah terhadap komponen tersebut menurut norma/standar yang berlaku. Lebih khusus lagi mutu pendidikan hanya dapat dilihat melalui mutu sekolah, sehingga dalam pengertian ini, mutu pendidikan diartikan kemampuan organisasi sekolah dalam pengelolaan secara operasional, efektif, dan efisien terhadap semua komponen yang berkaitan dengan sekolah, sehingga menghasilkan nilai tambah terhadap komponen tersebut menurut norma/standar yang berlaku.

Permasalahan mendasar pendidikan yang dihadapi oleh Kabupaten Gunungkidul dalam 5 tahun terakhir, selalu menempati peringkat terakhir (peringkat ke-5) di tingkat Dinas Pendidikan, Pemuda, dan Olahraga Daerah Istimewa Yogyakarta. Posisi ini tidak terlepas dari mutu pendidikan secara keseluruhan di tingkat Kabupaten Gunungkidul di mana terdapat kesenjangan pemerataan mutu pendidikan antar kecamatan di wilayah Gunungkidul. Sekolahsekolah yang memiliki mutu unggul dengan tenaga guru dan fasilitas yang mewadahi mengumpul di ibukota kecamatan dan kabupaten. Sementara sekolah-sekolah yang berada di pinggir kecamatan kurang memiliki tenaga guru yang cukup dan fasilitas seadanya. Kondisi ini tentu berakibat tidak meratanya mutu pendidikan di Kabupaten Gunungkidul.

Salah satu upaya peningkatan mutu pendidikan di Kecamatan Wonosari adalah memperkuat lembaga sekolah untuk meningkatkan mutu. Pemerintah, dalam hal Dinas Pendidikan, Pemuda, dan Olahraga dan Kemdikbud telah membuat peraturan perundang-undangan sistem peningkatan mutu pendidikan dengan mengadopsi Total Quality Management (TQM). Dilihat dari sejarah munculnya Total Quality Management (TQM) yang berasal dari dunia industri, maka strategi manajemen mutu terpadu di dunia pendidikan mengacu pada dunia industri. Strategi implementasi manajemen mutu terpadu dalam dunia pendidikan adalah institusi pendidikan yang memposisikan dirinya sebagai institusi penyedia jasa atau dengan kata lain institusi pendidikan memposisikan diri menjadi industri jasa, yakni institusi yang memberikan pelayanan (service) sesuai dengan apa yang diinginkan oleh pelanggan (costumer).

Pelanggan utama sekolah adalah siswa. Sekolah yang menerapkan manajemen mutu terpadu harus memperhatikan keinginan dan kepuasan siswa dalam pem- 
belajaran. Dalam konteks inilah guru sebagai pengendali utama proses belajar mengajar harus memiliki kompetensi yang memadai. Guru sebagai tenaga profesional mempunyai tugas sebagai pendidik profesional dengan tugas utama mendidik, mengajar, membimbing, mengarahkan, melatih, menilai, dan mengevaluasi peserta didik pada pendidikan anak usia dini jalur pendidikan formal, pendidikan dasar dan pendidikan menengah. Mendidik berarti meneruskan dan mengembangkan nilainilai hidup, mengajar berarti meneruskan dan mengembangkan ilmu pengetahuan, melatih berarti mengembangkan keterampilan-keterampilan pada siswa. Oleh karena itu, guru sebagai tenaga profesional harus selalu ditingkatkan profesionalitasnya.

Sistem Penjaminan Mutu Pendidikan (SPMP) yang dilaksanakan di SD Negeri Karangrejek II dan SD Muhammadiyah Al Mujahidin merupakan bagian dari Total Quality Management (TQM) adalah kebijakan strategis Kementerian Pendidikan dan Kebudayaan sebagai upaya mengatasi masalah-masalah pendidikan. Sistem Penjaminan Mutu Pendidikan (SPMP) merupakan kegiatan yang sistemik dan terpadu pada penyelenggaraan pendidikan untuk peningkatan mutu. Meski upaya peningkatan mutu melalui Sistem Penjaminan Mutu Pendidikan (SPMP) yang salah satunya melahirkan kebijakan Manajemen Peningkatan Mutu Berbasis Sekolah (MPMBS) ternyata belum banyak dikenal oleh masyarakat.

Masyarakat yang terdiri dari para orang tua murid tidak begitu memperdulikan sistem penjaminan mutu yang dijalankan. Mereka beranggapan sekolah yang bagus adalah sekolah yang mampu meraih prestasi akademik dan non-akademik yang tinggi. Prestasi akademik ditandai dengan capaian nilai Ujian Nasional (UN) yang tinggi dan menduduki peringkat atas di kecamatan atau kabupaten. Prestasi non-akademik ditandai dengan keberhasilan sekolah mengantarkan muridmuridnya menjuarai lomba di bidang olahraga atau seni.
Di sisi lain, SD Negeri Karangrejek II dan SD Muhammadiyah Al Mujahidin sebagai lembaga pendidikan di bawah Dinas Pendidikan, Pemerintah Daerah dan Kemdikbud mempunyai tugas dan fungsi pelaksanaan kebijakan pemerintah. Salah satunya adalah mengimplementasikan Sistem Penjaminan Mutu Pendidikan (SPMP) dari Lembaga Penjaminan Mutu Pendidikan (LPMP). Pelaksanaan Sistem Penjaminan Mutu Pendidikan (SPMP) diawali dengan pendidikan dan pelatihan (diklat) penjaminan mutu, pembentukan Tim Penjaminan Mutu Sekolah, dan pendampingan di lapangan oleh LPMP.

Dalam Permendiknas Tahun 2009 Nomor 63 disebutkan bahwa "Penjaminan mutu pendidikan formal dan nonformal dilaksanakan oleh satuan atau program pendidikan". Menurut peraturan ini penyelenggaraan satuan atau program pendidikan wajib menyediakan sumber daya yang diperlukan untuk terlaksananya penjaminan mutu. Implementasinya satuan pendidikan harus melaksanakan manajemen Sistem Penjaminan Mutu (SPM). Sayangnya kegiatan sosialisasi dan implementasi Sistem Penjaminan Mutu (SPM) sampai saat ini belum memasyarakat. Bahkan terdapat asumsi bahwa Sistem Penjaminan Mutu (SPM) hanya terbatas pada pembuatan dokumen mutu. Di samping itu Permendiknas Nomor 63 tahun 2009 tidak menunjuk secara langsung model penjaminan mutu yang harus dilaksanakan di sekolah. Pada pasal 10 disebutkan Penjaminan mutu pendidikan oleh satuan atau program pendidikan ditujukan untuk memenuhi tiga tingkatan acuan mutu, yaitu: Standar Pelayanan Minimal (SPM), Standar Nasional Pendidikan (SNP), dan standar mutu pendidikan di atas SNP. Standar pelayanan Minimal (SPM) bidang pendidikan adalah jenis dan tingkat pelayanan pendidikan minimal yang harus disediakan oleh satuan atau program pendidikan, penyelenggara satuan atau program pendidikan, pemerintah provinsi, dan pemerintah kabupaten atau kota sebagaimana diatur dalam Peraturan Pemerintah Nomor 38 Tahun 2007 tentang Pembagian Urusan 
Pemerintahan Antara Pemerintah, Pemerintahan Daerah Provinsi, dan Pemerintahan Daerah Kabupaten/Kota. Standar Nasional Pendidikan (SNP) adalah kriteria minimal tentang sistem pendidikan di seluruh wilayah hukum Negara Kesatuan Republik Indonesia berujud sebagaimana diatur dalam Peraturan Pemerintah Nomor 19 Tahun 2005 (sebagaimana telah direvisi dengan Peraturan Pemerintah Nomor 32 Tahun 2013) tentang Standar Nasional Pendidikan dan peraturan perundangan lain yang relevan. Standar mutu pendidikan di atas SNP dapat berupa: Standar mutu di atas SNP yang berbasis keunggulan lokal atau standar mutu di atas SNP yang mengadopsi dan/atau mengadaptasi standar internasional tertentu.

Implementasi Permendiknas Nomor 63 tahun 2009 di SD Negeri Karangrejek II dan SD Muhammadiyah Al Mujahidin diawali dengan pelaksanaan pendidikan dan pelatihan (diklat) kepala sekolah dan guru oleh Lembaga Penjaminan Mutu Pendidikan (LPMP) Daerah Istimewa Yogyakarta. Kegiatan pendidikan dan pelatihan yang awalnya bertujuan untuk peningkatan profesionalisme guru, hanya dipandang sebagai kegiatan rutinitas belaka, sebagai-mana diklat-diklat yang lainnya. Hasil dari kegiatan Pendidikan dan Latihan (Diklat) LPMP beberapa sekolah dasar yang berperingkat Sekolah Standar Nasional (SSN) mengimplementasikan Sistem Penjaminan Mutu (SPM) dalam bentuk prosedur mutu dan petunjuk kerja guna menerapkan 8 (delapan) Standar Nasional Pendidikan (SNP). Sekolah yang telah menerima diklat tergabung dalam sebuah kelompok, membentuk cluster. Cluster melaksanakan kegiatan pertemuan rutin membahas tindak lanjut diklat. Sisi kelemahan kegiatan ini hanya sebatas pada pemenuhan pembuatan dokumen mutu, belum pernah mengungkap tanggapan guru dalam kaitannya dengan perencanaan pembelajaran, pelaksanaan pembelajaran, penilaian proses pembelajaran, supervisi pembelajaran dan pengawasan pembelajaran.

Hasil kerja kegiatan dalam cluster berupa rancangan dokumen mutu dan petun- juk kerja. Rancangan ini ditindaklanjuti di SD Negeri Karangrejek II dan SD Muhammadiyah Al Mujahidin melalui Tim Penjaminan Mutu Sekolah. Sekolah dengan peringkat Sekolah Standar Nasional (SSN) telah menetapkan dokumen mutu dan petunjuk kerja dalam pelaksanaan standar proses, namun belum semua guru SDSN melaksanakan perencanaan sesuai dengan petunjuk kerja dokumen mutu.

Dokumen mutu dan petunjuk kerja yang dihasilkan oleh Tim Penjaminan Mutu Sekolah SD Negeri Karangrejek II dan SD Muhammadiyah Al Mujahidin merupakan pedoman pelaksanaan dalam membuat rencana kegiatan. Khusus untuk standar proses, petunjuk kerja (PK) merupakan acuan dalam menyusun silabus dan Rencana Pelaksanaan Pembelajaran (RPP). RPP diaplikasikan ke dalam pembelajaran di kelas. Sekolah dengan peringkat SDSN telah melaksanakan pembelajaran sesuai dengan standar proses, namun belum semua guru melaksanakannya. Demikian pula sekolah telah menetapkan petunjuk kerja pelaksanaan penilaian proses pembelajaran, namun belum semua guru melaksanakan sesuai dengan petunjuk kerja yang telah ditetapkan.

Perencanaan pembelajaran yang terdiri dari silabus dan Rencana Pelaksanaan Pembelajaran (RPP) memiliki peran penting. Dengan Rencana Pelaksanaan Pembelajaran (RPP) yang baik dan bermutu akan menghasilkan Pembelajaran Aktif, Inovatif, Kreatif, Efektif, dan Menyenangkan (PAIKEM). Namun masih terdapat guru yang mempunyai anggapan bahwa perencanaan pembelajaran hanyalah sekedar memenuhi kewajiban administrasi guru. Untuk kepentingan supervisi dan kenaikan pangkat.

Hal yang menarik dikaji adalah apakah implementasi Sistem Penjaminan Mutu (SPM) yang dilaksanakan oleh SD Negeri Karangrejek II dan SD Muhammadiyah Al Mujahidin sebagai hasil diklat dari LPMP sama dan serupa dengan Total Quality Management (TQM)? Sebab secara substansi memang terdapat kemiripan, namun pelaksanaan di lapangan terdapat beberapa 
hal yang berbeda antara Sistem Penjaminan Mutu Pendidikan (SPMP) dengan Total Quality Management (TQM), meski muara akhirnya memiliki kesamaan yaitu peningkatan mutu pendidikan. Dari observasi lapangan tanggal 30 April 2013 sampai dengan 10 Mei 2013didapat data awal bahwa SD Negeri Karangrejek II dan SD Muhammadiyah Al Mujahidin telah menerapkan Total Quality Management (TQM) untuk meningkatkan mutu pendidikan. Kasus di SD Negeri Karangrejek II dan SD Muhammadiyah Al Mujahidin meskipun filososfi dan prinsip-prinsip Total Quality Management (TQM) telah dilaksanakan dalam aktiviatas keseharian, tetapi secara konseptual TQM belum tersusun secara sistematis. Hal ini disebabkan tidak adanya pedoman yang jelas terhadap pelaksanaan Total Quality Management (TQM) di sekolah. Ketiadaan pedoman ini membuat keraguan lembaga sekolah dalam menerapkan Total Quality Management (TQM).

Sekolah Dasar Negeri Karangrejek II memiliki karakteristik yang unik. Keunikan tersebut tergambar dari sisi geografis sekolah ini terletak di pinggir kota Wonosari pada jalur utama wisata Gunungkidul. Sebagai pintu gerbang pariwisata, dan pembangunan wilayah pedesaan, Desa Karangrejek maju dengan sangat pesat. SD Negeri Karangrejek II juga memiliki keragaman masukan (input) siswa, latar belakang belakang orang tua/wali siswa yang heterogen, tingkat pendidikan masyarakat yang relatif menyebar dan kondisi lingkungan yang mendukung proses pendidikan secara optimal. SD Negeri Karangrejek II merupakan sekolah dasar negeri angkatan pertama yang memperoleh peringkat Sekolah Dasar Standar Nasional (SDSN) di lingkungan Dinas Pendidikan, Pemuda, dan Olahraga Kabupaten Gunungkidul.

Di sisi lain SD Muhammadiyah Al Mujahidin merupakan sekolah dasar swasta di bawah Perserikatan Muhammadiyah yang relatif baru berdiri di Kecamatan Wonosari. Meski baru berdiri namun kehadirannya telah menarik perhatian masyarakat Kecamatan Wonosari pada khususnya dan Kabupaten Gunungkidul umumnya. Seko- lah ini menerapkan sistem pendidikan yang berbeda dengan sekolah-sekolah lainnya yaitu sistem semi full-day school. Dengan sistem pendidikan seperti ini SD Muhammadiyah Al Mujahidin mampu menunjukkan prestasi akademik dan non-akademik di tingkat kabupaten, provinsi, nasional, bahkan tingkat internasional.

Berdasarkan hal-hal tersebut beberapa masalah implementasi Total Quality Management (TQM) pada Sekolah Dasar Negeri Karangrejek II dan SD Muhammadiyah Al Mujahidin, Kecamatan Wonosari, Kabupaten Gunungkidul sebagai berikut: (1) Total Quality Management (TQM) secara konseptual belum tersusun secara jelas; (2) Implementasi Sistem Penjaminan Mutu Pendidikan (SPMP) sampai saat ini belum memasyarakat; (3) Kegiatan Total Quality Management (TQM) hanya sebatas pada pemenuhan pembuatan dokumen mutu, belum pernah mengungkap tanggapan guru dalam kaitannya dengan perencanaan pembelajaran, pelaksanaan pembelajaran, penilaian proses pembelajaran, supervisi pembelajaran dan pengawasan pembelajaran; (4) belum semua guru SDSN melaksanakan perencanaan sesuai dengan petunjuk kerja dokumen mutu dan petunjuk kerja; (5) Terdapat keraguan penerapan Total Quality Management (TQM) pada sekolah dasar. Penelitian ini hanya membatasi pada permasalahan implementasi Total Quality Management (TQM) pada SD Negeri Karangrejek II dan SD Muhammadiyah Al Mujahidin, dengan rumusan masalah sebagai berikut: (1) Seberapa besar pelaksanaan Total Quality Management di SD Negeri Karangrejek II dan SD Muhammadiyah Al Mujahidin? (2) Bagaimana perbandingan Implementasi Total Quality Management antara SD Negeri Karangrejek II dengan SD Muhammadiyah Al Mujahidin? 3) Aspekaspek apa sajakah yang perlu mendapat perbaikan untuk ditingkatkan supaya mendekati standar dalam Implementasi Total Quality Management (TQM) di SD Negeri Karangrejek II dan SD Muhammadiyah Al Mujahidin?

Total Quality Management (TQM) Total Quality Management in Education (TQME) 
yang diterjemahkan ke dalam Bahasa Indonesia menjadi Manajemen Mutu Terpadu dalam Pendidikan, merupakan bagian kajian dan penerapan dari TQM.

Lunenburg menegaskan keberadaan TQM tidak hanya dapat diterapkan di dunia industri, melainkan dunia pendidikan juga di dunia pendikan.

TQM is a systematic approach to education reform based on the philosophy of W. Edwards Deming. Deming's work is not merely about productivity and quality control; it is a broad vision on the nature of organizations and how organizations should be changed. (Lunenburg, 2010, p.1).

Penegasan ini menunjukkan bahwa TQM adalah pendekatan sistematis untuk reformasi pendidikan berdasarkan filosofi W. Edwards Deming. Karya Deming adalah tidak hanya tentang produktivitas dan kualitas kontrol, namun berupa visi yang luas pada sifat organisasi dan bagaimana organisasi harus diubah. Ketika pendidik melihat prinsip-prinsip TQM, mereka menganggap bahwa model hanya berlaku untuk organisasi nirlaba atau industri. Sebenarnya TQM berlaku juga untuk perusahaan, organisasi layanan, universitas, dan sekolah dasar dan sekolah menengah. Konsep-konsep yang dirumuskan oleh pendiri TQM, W. Edwards Deming, memiliki bukti kuat sehingga pendidik dapat menerapkan TQM ke sekolah-sekolah. Filosofi Deming menyediakan kerangka kerja yang dapat mengintegrasikan berbagai perkembangan positif di bidang pendidikan, seperti istilah mengajar, manajemen berbasis situs, pembelajaran kooperatif, dan hasil berbasis proyek.

Senada dengan Lunenburg, Sharma (2012, p.1) berpendapat bahwa Total Quality Management (TQM) in Education is a timely tool, which must be clearly understood, adopted and implemented as soon as possible. Dalam pandangan ini Total Quality Management (TQM) dalam pendidikan dilihat sebagai sebuah alat yang kehadirannya tepat waktu, yang harus dipahami dengan jelas, diadopsi dan diimplementasikan sesegera mungkin di sekolah.

\section{Konsep Dasar Penjaminan Mutu Sekolah}

Konsep dasar penjaminan mutu sekolah sesuai Permendiknas nomor 63 tahun 2009 terdiri atas Standar mutu di atas Standar Nasional Pendidikan (SNP) yang berbasis keunggulan lokal. Artinya apabila sebuah sekolah telah melampaui Standar Nasional Pendidikan (SNP) dikatakan sekolah yang bermutu yang disebut dengan sekolah mandiri. Di samping menggunakan SNP sebagai acuan peningkatan mutu, sekolah juga dapat menggunakan standar mutu di atas SNP yang mengadopsi dan/ atau mengadaptasi standar internasional tertentu.

Sistem penjaminan mutu (quality assurance) pendidikan sesungguhnya tidaklah sama (atau sesuatu yang berbeda) dengan mutu pendidikan (quality of education) itu sendiri. Mutu pendidikan lebih sebagai wujud terbaik yang dihasilkan oleh proses pembelajaran optimal di satuan pendidikan. Jadi, mutu pendidikan berfokus pada kualitas sosok yang tercipta sesuai yang diharapkan. Sementara sistem penjaminan mutu pendidikan merupakan siklus manajemen dalam penyelenggaraan pendidikan yang meliputi kegiatan mengukur, mengevaluasi, dan mengawal mutu, menyangkut praktik dan tradisi akademik dan non akademik pada satuan pendidikan.

Sistem penjaminan mutu pendidikan menjadi penting untuk memantau dan memastikan setiap program/jurusan dan institusi satuan pendidikan diselenggarakan sesuai standar mutu pendidikan. Citra pendidikan juga turut terjaga dengan adanya kegiatan penjaminan mutu (internal dan eksternal) yang dilakukan oleh lembaga independen yang memiliki perangkat kerja yang jelas dan terbuka untuk diakses publik. Salah satu sistem peningkatan mutu pendidikan yang diterapkan di Indonesia adalah model Manajemen Peningkatan Mutu Berbasis Sekolah (MPMBS).

Pemberian kewenangan kepada sekolah untuk menentukan proses pengelolaan pendidikan secara mandiri merupakan inti dari model Manajemen Peningkatan Mutu Berbasis Sekolah (MPMBS). Secara 
umum manajemen peningkatan mutu berbasis sekolah (MPMBS) dapat diartikan sebagai model manajemen yang memberikan otonomi lebih besar kepada sekolah dan mendorong pengambilan keputusan partisipatif yang melibatkan secara langsung semua warga sekolah (guru, siswa, kepala sekolah, karyawan, orang tua siswa, dan masyarakat) untuk meningkatkan mutu sekolah berdasarkan kebijakan pendidikan nasional (Depdiknas, 2001, p.3). Dengan otonomi yang lebih besar, sekolah memiliki kewenangan yang lebih besar dalam mengelola dan mengembangkan programprogramnya yang lebih sesuai dengan dengan kebutuhan dan potensi yang dimilikinya.

Manajemen Peningkatan Mutu Berbasis Sekolah (MPMBS) memiliki karakteristik berdasarkan pendekatan sistem yang bertumpu pada input-proses-output. Subsistem input terdiri dari: (a) sekolah memiliki kebijakan, tujuan, sasaran mutu yang jelas, (b) sumber daya tersedia dan siap, (c) staf yang berkompeten dan berdedikasi tinggi, (d) memiliki harapan prestasi yang tinggi, (e) fokus pada pelanggan (khususnya siswa), dan (f) input manajemen. Subsistem proses pada umumnya sekolah harus memiliki karakteristik (a) proses belajar mengajar yang efektifitasnya tinggi, (b) kepemimpinan sekolah yang kuat, (c) lingkungan sekolah yang aman dan tertib, (d) pengelolaan tenaga kependidikan yang efektif, (e) sekolah memiliki budaya mutu, (f) sekolah memiliki team work yang kompak, cerdas, dan dinamis g) sekolah memiliki kewenangan (kemandirian), h) partisipasi yang tinggi dari warga sekolah dan masyarakat, (i) sekolah memiliki keterbukaan (transparansi manajemen), (j) sekolah memiliki kemauan untuk berubah (psikologi dan fisik), (k) sekolah melakukan evaluasi dan perbaikan secara berkelanjutan, (l) sekolah responsif dan antisipatif terhadap kebutuhan, m) komunikasi yang baik, dan (n) sekolah memiliki akuntabilitas. Subsistem output adalah harapan prestasi sekolah yang dihasilkan oleh proses pembelajaran dan manajemen di sekolah. Output dapat diklasifikasikan menjadi
2 macam yaitu: prestasi akademik (academic achievement) dan output prestasi non-akademik (non-academic achievement).

ISO 9001: 2000 merupakan sistem manajemen mutu yang bisa diterapkan oleh sekolah, di samping Manajemen Peningkatan Mutu Berbasis Sekolah (MPMBS). ISO 9001 merupakan salah satu dari standar internasional untuk Sistem Manajemen Mutu (SMM). Terdapat 8 (delapan) prinsip dasar manajemen mutu berdasarkan standar ISO 9001, yaitu.

a) Pusat perhatian pada pelanggan

Pelanggan merupakan pemasok utama keberlangsungan hidup sebuah lembaga, termasuk lembaga pendidikan. Seluruh staf dan karyawan harus memahami dan menyadari bahwa kelangsungan hidup lembaga sangat bergantung pada pelanggan. Oleh karena itu semua pihak harus berusaha semaksimal mungkin untuk memenuhi dan kalau bisa melampaui harapan pelanggan, sehingga mereka puas menjadi pelanggan lembaga.

b) Kepemimpinan

Kepemimpinan sangat berpengaruh bagi jalannya sebuah institusi pendidikan. Pimpinan pada semua tingkatan harus mampu menciptakan dan memelihara lingkungan intern unit kerjanya sehingga semua staf dan karyawan di unit kerja tersebut dapat melibatkan diri secara penuh dalam upaya melaksanakan misi untuk mewujudkan visi lembaga.

c) Pelibatan orang

Melibatkan secara aktif semua staf dan karyawan merupakan inti sebuah organisasi. Oleh karena itu pelibatan orang mutlak dilakukan untuk melaksanakan kegiatan. Kemampuan semua orang perlu didayagunakan secara maksimal untuk manfaat unit kerja dan lembaga.

d) Pendekatan proses

Hasil yang dikehendaki akan tercapai lebih efisien apabila dalam melaksanakan suatu kegiatan sumber daya terkait dikelola sebagai suatu proses.

e) Pendekatan sistem pada manajemen

Mengetahui, memahami, dan mengelola proses yang saling terkait sebagai suatu sistem memberi sumbangan pada ke- 
efektifan dan efisiensi lembaga dalam mencapai tujuannya.

f) Perbaikan berlanjut

Perbaikan berlanjut (continual improvement) dari kinerja organisasi secara keseluruhan harus menjadi tujuan tetap dari organisasi. Perbaikan berkesinambung didefinisikan sebagai suatu proses yang berfokus pada upaya terus-menerus meningkatkan efektivitas dan/atau efisiensi organisasi untuk memenuhi kebijakan dan tujuan dari organisasi itu. Perbaikan berkesinambung membutuhkan langkah-langkah konsolidasi yang progresif, merespon perkembangan kebutuhan dan ekspektasi pelanggan sehingga akan menjamin suatu evolusi dinamis dari sistem manajemen mutu.

g) Pendekatan fakta dalam pengambilan keputusan

Keputusan yang efektif adalah yang berdasarkan pada analisis data dan informasi untuk menghilangkan akar penyebab masalah, sehingga masalah-masalah mutu dapat terselesaikan secara efektif dan efisien. Keputusan manajemen organisasi sebaiknya ditujukan untuk meningkatkan kinerja organisasi dan efektivitas implementasi sistem manajemen mutu.

h) Hubungan pemasok yang saling menguntungkan.

Semua pihak harus menyadari bahwa suatu organisasi dan pemasok saling bergantung satu sama lain, karena itu harus dibangun hubungan saling menguntungkan guna meningkatkan kemampuan keduanya dan menciptakan nilai tambah.

\section{Metode Penelitian}

Penelitian ini termasuk jenis penelitian evaluatif yaitu penelitian non-hipotesis, tetapi hanya mengungkap gejala yang ada pada saat penelitian dilaksanakan. Penelitian evaluatif adalah penelitian evaluasi yang dilakukan untuk mengetahui nilai variabel mandiri, baik satu variabel atau lebih tanpa membuat perbandingan atau menghubungkan antara variabel satu de- ngan variabel yang lain. Pendekatan penelitian yang digunakan adalah penelitian jenis evaluasi program dengan menggunakan model discrepancy evaluation atau evaluasi kesenjangan yang membandingkan antara tujuan atau standar dengan hasil pelaksanaan yang sesungguhnya, yang difokuskan pada implementasi TQM.

Desain penelitian ini melihat pelaksanaan TQM di SD Negeri Karangrejek II dan SD Muhammadiyah Al Mujahidin. Apakah pelaksanaan TQM pada kedua sekolah tersebut sudah sesuai dengan pedoman atau tidak?

Penelitian ini terdiri dari kegiatan pengumpulan data, pengelompokan data untuk memperoleh informasi tentang tanggapan guru dan kepala sekolah terhadap implementasi TQM.

Jenis, Waktu, dan Tempat Penelitian

Penelitian ini merupakan penelitian evaluatif model descrepancy. Penelitian dilaksanakan 5 September 2013 sampai dengan 5 Desember 2013 di SD Negeri Karangrejek II dan SD Muhammadiyah Al Mujahidin, Kecamatan Wonosari, Kabupaten Gunungkidul.

\section{Prosedur}

Fernandes (1984, p.9) menyatakan proses evaluasi kesenjangan terdiri atas lima tahap yang digambarkan dalam bagan berikut.

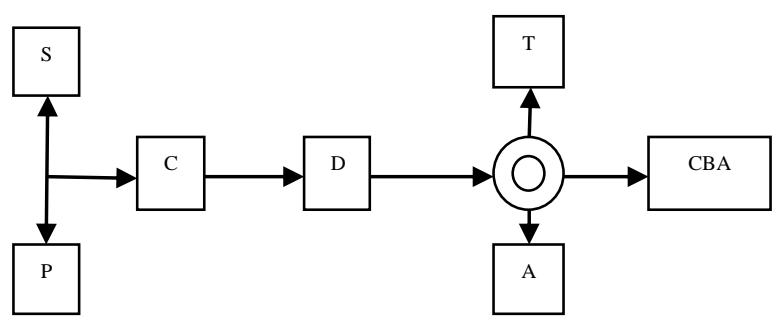

Gambar 1. Desain Evaluasi Kesenjangan

Keterangan:

$S$ : Standard

P : Program Perfomance

C : Comparison of $S$ with $\mathrm{P}$

D : Descrepancy information resulting from $C$

$\mathrm{T}$ : Terminate

A : Alteration of $\mathrm{P}$ or $\mathrm{S}$

CBA : Cost benefit Analysis 
Langkah-langkah atau tahap-tahap dalam mengevaluasi kesenjangan meliputi lima tahapan. Tahapan-tahapan tersebut adalah sebagai berikut.

\section{Penyusunan Desain}

Dalam tahap desain, fokus kegiatan dilakukan untuk merumuskan tujuan, proses atau aktifitas, serta pengalokasian sumber daya dan partisipan untuk melakukan aktifitas dan mencapai tujuan-tujuan yang telah ditetapkan. Menurut Provus, program pendidikan merupakan system dinamis yang meliputi input (antecedent), proses, dan outputs (juga outcomes). Standar atau harapan-harapan yang ingin dicapai ditentukan untuk masing-masing komponen tersebut. Standar ini merupakan tujuan program yang kemudian menjadi kriteria dalam kegiatan penilaian yang dilakukan.

Dengan demikian dalam tahap ini kegiatan yang dilakukan adalah: Merumuskan tujuan program, menyiapkan murid, staf dan kelengkapan lain dan merumuskan standar dalam bentuk rumusan yang menunjuk pada suatu yang dapat diukur, biasa di dalam langkah ini evaluator berkonsultasi dengan pengembangan program.

\section{Instalasi}

Tahap instalasi adalah penetapan kelengkapan program (installation), yaitu melihat apakah kelengkapan yang tersedia sudah sesuai dengan yang diperlukan atau belum. Selama tahap instalasi, rancangan program digunakan sebagai standar untuk mempertimbangkan langkah-langkah operasional program. Seorang evaluator perlu mengembangkan seperangkat tes kongruensi untuk mengidentifikasi tiap kesenjangan antara instalasi program atau aktifitas yang diharapkan dan yang aktual. Hal ini perlu untuk meyakinkan bahwa program telah diinstal sesuai dengan rancangan yang ditetapkan.

Dalam tahap ini dilakukan kegiatan: meninjau kembali penetapan standar, meninjau kembali program yang sedang berjalan dan meneliti kesenjangan antara yang direncanakan dengan yang sudah dicapai.

\section{Proses}

Pada tahap proses, evaluasi difokuskan pada upaya bagaimana memperoleh data tentang kemajuan para peserta program, untuk menentukan apakah perilakunya berubah sesuai dengan yang diharapkan atau tidak. Jika ternyata tidak, maka perlu dilakukan perubahan terhadap aktivitas-aktivitas yang diarahkan untuk mencapai tujuan perubahan perilaku tersebut. Tahap ini juga disebut tahap "mengumpulkan data dari pelaksanaan program".

\section{Tahap Pengukuran Tujuan (Product)}

Yaitu tahap mengadakan analisis data dan menetapkan tingkat output yang diperoleh. Pertanyaan yang diajukan dalam tahap ini adalah apakah program sudah mencapai tujuan akhirnya?"

Selama tahap produk, penilaian dilakukan untuk menentukan apakah tujuan akhir program tercapai atau tidak. Provus membedakan antara dampak terminal (immediate outcomes) dan dampak jangka panjang (long term-outsomes). Dengan pemikiran ini ia mendorong evaluator untuk tidak hanya mengevaluasi hasil berupa kinerja program, tetapi lebih dari itu perlu mengadakan studi lanjut sebagai bagian dari evaluasi.

\section{Perbandingan program (Program comparison)}

Yaitu tahap membandingkan hasil yang telah dicapai dengan tujuan yang telah ditetapkan. Dalam tahap ini evaluator menuliskan semua penemuan kesenjangan untuk disajikan kepada para pengambil keputusan, agar dapat memutuskan kelanjutan dari program tersebut. Kemungkinannya adalah: (a) menghentikan program (b) mengganti atau merevisi (c) meneruskan (d) memodikfikasi tujuannya.

Instrumen penelitian berupa angket yang telah mendapatkan judgment dari dosen ahli diujicobakan ke kepala sekolah dan guru sekolah dasar yang berperingkat Sekolah Dasar Standar Nasional (SDSN) di luar kecamatan Wonosari. Uji validitas instrumen dilakukan dengan dua cara, yaitu validitas ahli (face validity atau expert 
judgment) dan validitas isi (content validity). Instrumen diujicobakan ke 39 responden kepala sekolah dan guru sekolah dasar yang berperingkat SDSN. Penghitungan koefisien validitas instrumen menggunakan korelasi Product moment. Koefisien reliabilitas dihitung menggunakan formula Kuder-Richardson (KR20). Setelah dilakukan uji validitas dan uji reliabilitas instrumen penelitian disebar ke Kepala Sekolah dan guru SD Karangrejek II dan SD Muhammadiyah $\mathrm{Al}$ Mujahidin untuk mendapatkan data primer.

Data, Intrumen, dan Teknik Pengumpulan Data

Jenis data yang digunakan dalam penelitian ini adalah data primer dan data sekunder. Untuk memperoleh data primer instrumen yang digunakan adalah angket model tertutup (closed ended). Terdiri dari 69 item pertanyaan dengan jawaban skala 2 (skala Guttman). Data sekunder diperoleh dengan dokumentasi.

Unit Analisis

Unit analisis diartikan sebagai the primary focus of data collection will be on what is happening to individuals in a setting and how individuals are affected by the setting (Patton, 2002, p.228). Fokus utama dalam pengumpulan data tentang apa yang terjadi pada individu dalam sebuah pengaturan (setting) dan bagaimana individu tersebut dipengaruhi oleh pengaturan (setting). Berdasarkan pengertian ini unit analisis diartikan sebagai segala sesuatu yang akan menjadi obyek atau fokus penelitian atau pengamatan dalam penelitian evaluasi.

Unit analisis penelitian ini adalah implementasi TQM. Data yang dikumpulkan terkait dengan beberapa komponen yang mempengaruhi implementasi TQM di SD Negeri Karangrejek II dan SD Muhammadiyah Al Mujahidin, Wonosari yaitu: (1) perbaikan terus menerus, (2) Kaizen, (3) perubahan kultur, (4) organisasi terbalik, (5) menjaga hubungan dengan pelanggan, (6) kolega sebagai pelanggan, (7) pemasaran internal, (8) profesionalisme, (9) Mutu pembelajaran

Standar Evaluasi yang Digunakan.

Penerapan Sistem Penjaminan Mutu (SPM) di sekolah dapat memilih dari model-model yang ada, sesuai dengan kebutuhan dan kondisi sekolah. Model standar mutu yang bisa dilaksanakan misalnya: Model TQM, ISO, Kaizen, Model QAFU, National University of Singapore, atau model yang dilaksanakan oleh LPMP.

Standar atau pedoman evaluasi yang digunakan untuk mengevaluasi implementasi Total Quality Management (TQM) adalah sintesa yang memadukan model SPMP LPMP Daerah Istimewa Yogyakarta yang mengacu pada karakteristik Manajemen Peningkatan Mutu Berbasis Sekolah dan prinsip-prinsip ISO 9001: 2000. Terdapat kesesuaian antara aspek-aspek dalam Karakteristik MPMBS dan prinsip ISO 9001: 2000 sebagai pedoman baku dalam Sistem Manajemen Mutu dengan aspek-aspek Total Quality Management in Education. Kesesuaian tersebut terletak pada aspek: (a) perbaikan terus menerus sesuai dengan karakteristik MPMBS sekolah memiliki kemauan untuk berubah dan prinsip ISO perbaikan berlanjut; (b) Kaizen merupakan penjabaran dari kepemimpinan sekolah; (c) Perubahan kultur sesuai dengan karakteristik MPMBS subsistem sekolah memiliki kebijakan, tujuan, dan sasaran mutu yang jelas serta prinsip pendekatan sistem pada manajemen; (d) Organisasi terbalik sesuai karakteristik sekolah memiliki team work, yang kompak, cerdas, dan dinamis serta prinsip pendekatan proses; (e) menjaga hubungan dengan pelanggan sesuai prinsip MPMBS fokus pada pelanggan dan prinsip pusat perhatian pada pelanggan; (f) kolega sebagai pelanggan sesuai dengan karakteristik komunikasi yang baiki dan prinsip hubungan pemasok yang saling menguntungkan; (g) pemasaran internal sesuai dengan dengan karakteristik sumber daya tersedia dan siap serta prinsip pelibatan orang; (h) profesionalisme merupakan penjabaran dari karakteristik sekolah responsif 
dan antisipatif terhadap kebutuhan serta prinsip pendekatan fakta dalam pengambilan keputusan; (i) mutu pembelajaran sesuai dengan karakteristik proses belajar mengajar yang efektivitasnya tinggi.

Pedoman/standar evaluasi tersebut dirangkum dan disajikan pada Tabel 1.

Tabel 1. Standar Evaluasi

\begin{tabular}{|c|c|c|c|}
\hline \multirow[b]{2}{*}{ No } & \multirow{2}{*}{$\begin{array}{c}\text { Standar/Pedoman } \\
\text { Evaluasi }\end{array}$} & \multicolumn{2}{|c|}{ Diturunkan dari } \\
\hline & & MPMBS & $\begin{array}{c}\text { Prinsip ISO } \\
9001: 2000\end{array}$ \\
\hline 1 & $\begin{array}{l}\text { Perbaikan terus } \\
\text { menerus }\end{array}$ & $\begin{array}{l}\text { Sekolah memiliki } \\
\text { kemauan untuk } \\
\text { berubah }\end{array}$ & $\begin{array}{l}\text { Perbaikan } \\
\text { berlanjut }\end{array}$ \\
\hline 2 & Kaizen & $\begin{array}{l}\text { Kepemimpinan } \\
\text { sekolah yang kuat }\end{array}$ & Kepemimpinan \\
\hline 3 & Perubahan kultur & $\begin{array}{l}\text { Memiliki kebijakan, } \\
\text { tujuan, dan sasaran } \\
\text { mutu yang jelas }\end{array}$ & $\begin{array}{l}\text { Pendekatan } \\
\text { sistem pada } \\
\text { manajemen }\end{array}$ \\
\hline 4 & Organisasi terbalik & $\begin{array}{l}\text { Sekolah memiliki } \\
\text { teamwork yang } \\
\text { kompak, cerdas, } \\
\text { dan dinamis }\end{array}$ & $\begin{array}{l}\text { Pendekatan } \\
\text { proses }\end{array}$ \\
\hline 5 & $\begin{array}{l}\text { Menjaga hubungan } \\
\text { dengan pelanggan }\end{array}$ & $\begin{array}{l}\text { Fokus pada } \\
\text { pelanggan }\end{array}$ & $\begin{array}{l}\text { Pusat perhatian } \\
\text { pada pelanggan }\end{array}$ \\
\hline 6 & $\begin{array}{l}\text { Kolega sebagai } \\
\text { pelanggan }\end{array}$ & $\begin{array}{l}\text { Komunikasi yang } \\
\text { baik }\end{array}$ & $\begin{array}{l}\text { Hubungan } \\
\text { pemasok yang } \\
\text { saling } \\
\text { menguntungkan }\end{array}$ \\
\hline 7 & $\begin{array}{l}\text { Pemasaran inter- } \\
\text { nal }\end{array}$ & $\begin{array}{l}\text { Sumber daya } \\
\text { tersedia dan siap }\end{array}$ & Pelibatan orang \\
\hline 8 & Profesionalisme & $\begin{array}{l}\text { Sekolah responsif } \\
\text { dan antisipatif } \\
\text { terhadap } \\
\text { kebutuhan }\end{array}$ & $\begin{array}{l}\text { Pendekatan } \\
\text { fakta } \\
\text { dalam } \\
\text { pengambilan } \\
\text { keputusan }\end{array}$ \\
\hline 9 & $\begin{array}{l}\text { Mutu pembelajar- } \\
\text { an }\end{array}$ & $\begin{array}{l}\text { Proses belajar } \\
\text { mengajar yang } \\
\text { efektivitasnya } \\
\text { tinggi }\end{array}$ & \\
\hline
\end{tabular}

Teknik Analisis Data

Teknik analisis data yang digunakan dengan teknik persentase, dengan ketentuan penskoran dan langkah-langkah sebagai berikut: (1) memberikan skor terhadap setiap indikator pelaksanaan program, masing-masing butir indikator apabila jawaban benar diberi skor 1 , apabila salah skornya 0 ; (2) menghitung persentase ketercapaian semua indikator dalam satu unit analisis; (3) mencari rata-rata yang dicapai setiap unit analisis; (4) mencari persentase unit analisis; (5) menarik kesimpulan.

Untuk menentukan kriteria kecenderungan implementasi TQM masing-masing unit analisis terdapat 5 (lima) standar yang dapat digunakan, yaitu: (1) traditional scientific research criteria; (2) social construction and constructivist criteria; (3) artistic and evocative criteria; (4) critical change criteria; (5) Evaluation standards and principles (Patton, 2002, p.542).

Pengambilan kesimpulan pada penelitian ini menggunakan standar nomor 5 yaitu evaluation standards and principles, yaitu standar evaluasi dan prinsip-prinsip dengan alasan paling sesuai untuk mengevaluasi implementasi TQM bila dibandingkan dengan empat standar lainnya.

\section{Hasil Penelitian dan Pembahasan}

Besaran Implementasi Total Quality Management (TQM) di SD Negeri Karangrejek II dan SD Muhammadiyah Al Mujahidin.

Hasil penelitian menunjukkan ratarata implementasi Total Quality Management (TQM) di SD Negeri Karangrejek II sebesar $87,73 \%$ rata-rata kesenjangan (descrepancy) sebesar $12,26 \%$ dengan standar deviasi sebesar 6,40. Aspek dengan skor tertinggi adalah mutu pembelajaran dengan total rata-rata sebesar $98,46 \%$, tingkat kesenjangan 1,54\%. Sedangkan aspek dengan skor terendah adalah perbaikan terus-menerus dengan rata-rata 78,84\%. Rata-rata sebesar itu menyumbang kesenjangan (descrepancy) sebesar 21,16\%.

Hasil penelitian juga menunjukkan aspek-aspek yang berada di atas rata-rata adalah: aspek perubahan kultur dengan skor sebesar 90,00\%; organisasi terbalik dengan skor sebesar $92,30 \%$; aspek kolega sebagai pelanggan dengan skor sebesar $90 \%$; aspek pemasaran internal dengan skor sebesar $88,46 \%$ dan aspek profesionalisme dengan skor sebesar 90,00\%. Sedangkan aspek-aspek yang berada di bawah ratarata adalah kaizen dengan skor sebesar $80,76 \%$ dan aspek menjaga hubungan dengan pelanggan dengan skor sebesar $80,76 \%$.

Capaian skor implementasi TQM di SD Karangrejek II sebagaimana disajikan pada Tabel 2. 
Tabel 2. Skor Capaian Implementasi TQM pada SD Negeri Karangrejek II

\begin{tabular}{llcc}
\hline No & \multicolumn{1}{c}{ Aspek Penilaian } & $\begin{array}{c}\text { Skor } \\
\text { Capaian }\end{array}$ & $\begin{array}{c}\text { Kesen- } \\
\text { jangan }\end{array}$ \\
\hline 1 & Perbaikan terus menerus & 78,84 & 21,16 \\
2 & Kaizen & 80,76 & 19,24 \\
3 & Perubahan kultur & 90,00 & 10,00 \\
4 & Organisasi terbalik & 92,30 & 7,70 \\
5 & Menjaga hubungan dengan & 80,76 & 19,24 \\
& pelanggan & & \\
6 & Kolega sebagai pelanggan & 90,00 & 10,00 \\
7 & Pemasaran internal & 88,46 & 11,54 \\
8 & Profesionalisme & 90,00 & 10,00 \\
9 & Mutu pembelajaran & 98,46 & 1,54 \\
& Jumlah & 789,58 & 110,42 \\
& Rata-rata & 87,73 & 12,26 \\
& Standar Deviasi & 6,40 & 6,40 \\
\hline
\end{tabular}

Dari data Tabel 2 terdapat 3 aspek yang capaian skornya di bawah rata-rata. Aspek-aspek tersebut dimuat pada Tabel 3.

Tabel 3. Implementasi TQM pada SD Negeri Karangrejek II dengan Skor di Bawah Rata-Rata

\begin{tabular}{llcc}
\hline No & \multicolumn{1}{c}{ Aspek } & $\begin{array}{c}\text { Skor } \\
\text { Capaian }\end{array}$ & $\begin{array}{c}\text { Kesen- } \\
\text { jangan }\end{array}$ \\
\hline 1 & Perbaikan terus menerus & 78,84 & 21,16 \\
2 & Kaizen & 80,76 & 19,24 \\
3 & Menjaga hubungan dengan & 80,76 & 19,24 \\
& pelanggan & \\
\hline
\end{tabular}

Sedangkan aspek-aspek yang mencapai skor di atas rata-rata, sejumlah 6 aspek disajikan pada Tabel 4.

Tabel 4. Implementasi TQM pada SD Negeri Karangrejek II yang Mendekati Standar

\begin{tabular}{clcc}
\hline No & \multicolumn{1}{c}{ Aspek } & $\begin{array}{c}\text { Skor } \\
\text { Capaian }\end{array}$ & $\begin{array}{c}\text { Kesen- } \\
\text { jangan }\end{array}$ \\
\hline 1 & Mutu pembelajaran & 98,46 & 1,54 \\
2 & Organisasi terbalik & 92,30 & 7,70 \\
3 & Perubahan kultur & 90,00 & 10,00 \\
4 & Kolega sebagai pelanggan & 90,00 & 10,00 \\
5 & Profesionalisme & 90,00 & 10,00 \\
6 & Pemasaran internal & 88,46 & 11,54 \\
\hline
\end{tabular}

Hasil penelitian juga menunjukkan bahwa rata-rata implementasi Total Quality Management (TQM) di SD Muhammadiyah Al Mujahidin sebesar 94,42\% dengan tingkat kesenjangan sebesar 5,57\%, dan standar deviasi 3,20. Aspek dengan rata-rata tertinggi adalah organisasi terbalik dengan rata-rata $98,75 \%$, dan aspek terendah adalah perbaikan terus-menerus dengan ratarata sebesar $87,50 \%$. Beberapa aspek yang berada di atas rata-rata diantaranya adalah: aspek kaizen dengan rata-rata 94,79\%; perubahan kultur dengan rata-rata sebesar 95,70\%; menjaga hubungan dengan pelanggan menyumbang rata-rata sebesar $94,53 \%$; aspek profesionalisme dengan rata-rata sebesar 94,79\% dan aspek mutu pembelajaran dengan rata-rata $97,50 \%$. Sedangkan aspek kolega sebagai pelanggan dengan rata-rata $92,50 \%$ dan aspek pemasaran internal dengan nilai rata-rata $93,75 \%$ menjadi 2 aspek yang berada di bawah ratarata. Dua aspek ini menjadi aspek yang berada di bawah rata-rata disebabkan karena SD Muhammadiyah Al Mujahidin mmiliki standar yang baku dalam penerimaan siswa baru.

Data penelitian ini juga menunjukkan perbedaan antara SD Muhammadiyah Al Mujahidin dengan SD Karangrejek II. Capaian skor implementasi TQM di SD Muhammadiyah Al Mujahidin sebagaimana tercantum dalam Tabel 5.

Tabel 5. Skor Capaian Implementasi TQM pada SD Muhammadiyah Al Mujahidin

\begin{tabular}{llcc}
\hline No & \multicolumn{1}{c}{ Aspek Penilaian } & $\begin{array}{c}\text { Skor } \\
\text { Capaian }\end{array}$ & $\begin{array}{c}\text { Kesen- } \\
\text { jangan }\end{array}$ \\
\hline 1 & Perbaikan terus menerus & 87,50 & 12,50 \\
2 & Kaizen & 94,79 & 5,21 \\
3 & Perubahan kultur & 95,70 & 4,30 \\
4 & Organisasi terbalik & 98,75 & 1,25 \\
5 & Menjaga hubungan dengan & 94,53 & 5,47 \\
& pelanggan & 92,50 & 7,50 \\
6 & Kolega sebagai pelanggan & 93,75 & 6,25 \\
7 & Pemasaran internal & 94,79 & 5,21 \\
8 & Profesionalisme & 97,50 & 2,50 \\
9 & Mutu pembelajaran & 849,81 & 50,19 \\
& Jumlah & 94,42 & 5,57 \\
& Rata-rata & 3,20 & 3,20 \\
\hline
\end{tabular}

Sama halnya dengan SD Karangrejek II, pada SD Muhammadiyah Al Mujahidin juga terdapat 6 aspek yang mencapai skor di atas rata-rata atau mendekati standar. Aspek-aspek tersebut sebagaimana disajikan pada Tabel 6. 
Tabel 6. Implementasi TQM pada SD Muhammadiyah Al Mujahidin yang Mendekati Standar

\begin{tabular}{llcc}
\hline No & \multicolumn{1}{c}{ Aspek } & $\begin{array}{c}\text { Skor } \\
\text { Capaian } \\
\text { (dalam \%) }\end{array}$ & $\begin{array}{c}\text { Kesen- } \\
\text { jangan }\end{array}$ \\
\hline 1 & Organisasi terbalik & 98,75 & 1,25 \\
2 & Mutu pembelajaran & 97,50 & 2,50 \\
3 & Perubahan kultur & 95,70 & 4,30 \\
4 & Profesionalisme & 94,79 & 5,21 \\
5 & Kaizen & 94,79 & 5,21 \\
6 & $\begin{array}{l}\text { Menjaga hubungan } \\
\text { dengan pelanggan }\end{array}$ & 94,53 & 5,47 \\
\hline
\end{tabular}

Terdapat 3 aspek yang capaian skornya di bawah standar. Aspek-aspek tersebut disajikan pada Tabel 7 .

Tabel 7. Implementasi TQM pada SD Muhammadiyah Al Mujahidin dengan skor di bawah rata-rata standar

\begin{tabular}{llcc}
\hline No & \multicolumn{1}{c}{ Aspek Penilaian } & $\begin{array}{c}\text { Skor } \\
\text { Capaian } \\
\text { (dalam \%) }\end{array}$ & $\begin{array}{c}\text { Kesen- } \\
\text { jangan }\end{array}$ \\
\hline 1 & Perbaikan terus menerus & 87,50 & 12,50 \\
2 & Kolega sebagai pelanggan & 92,50 & 7,50 \\
3 & Pemasaran internal & 93,75 & 6,25 \\
\hline
\end{tabular}

Perbandingan Implementasi Total Quality Management (TQM) SD Negeri Karangrejek II dengan SD Muhammadiyah Al Mujahidin

Hasil penelitian menunjukkan aspek mutu pembelajaran merupakan aspek dengan capaian skor tertinggi di SD Negeri Karangrejek II, sedangkan di SD Muhammadiyah Al Mujahidin, skor dengan capaian tertinggi adalah aspek organisasi terbalik. Perbandingan capaian skor implementasi TQM di kedua sekolah disajikan pada Tabel 8.

Hasil penelitian yang menunjukkan aspek mutu pembelajaran mendapatkan skor tertinggi di SD Negeri Karangrejek II dengan total rata-rata sebesar 98,46\%, tingkat kesenjangan 1,54\%, jika dihubungkan dengan dengan beberapa literatur tentang TQM terdapat kesesuaian antara hasil penelitian dengan pendapat Sallis yang menyatakan bahwa Education is about learn- ing. Pendidikan adalah berhubungan dengan pembelajaran. Inti dari pendidikan adalah pelaksanaan pembelajaran yang membelajarkan siswa di kelas. Jika TQM memiliki relevansi dalam pendidikan, maka Sallis (2002, p.32) berpendapat “...it needs to address the quality of the learners' experience. Unless it does that, it will not make a substantial contribution to quality in education". Sebaliknya jika TQM tidak mampu menciptakan kualitas pembelajaran maka secara substansi TQM tidak akan memberikan kontribusi kualitas pada pendidikan. Senada dengan Sallis, prinsip Deming mengisyaratkan bahwa fokus Total Quality Management in Education (TQME) adalah upaya peningkatan pendidikan di bawah pendekatan pada proses belajar-mengajar. Guru harus mampu meningkatkan gaya dan kualitas pembelajaran di kelas.

Tabel 8. Perbandingan Skor Capaian Implementasi TQM

\begin{tabular}{|c|c|c|c|c|c|}
\hline \multirow{2}{*}{ No } & \multirow{2}{*}{ Aspek } & \multicolumn{2}{|c|}{ SD Kr. Rejek II } & \multicolumn{2}{|c|}{$\begin{array}{l}\text { SD. Muh. Al } \\
\text { Mujahidin }\end{array}$} \\
\hline & & $\begin{array}{c}\text { Skor } \\
\text { Capaian }\end{array}$ & $\begin{array}{l}\text { Kesen- } \\
\text { jangan }\end{array}$ & $\begin{array}{c}\text { Skor } \\
\text { Capaian }\end{array}$ & $\begin{array}{l}\text { Kesen- } \\
\text { jangan }\end{array}$ \\
\hline 1 & $\begin{array}{l}\text { Perbaikan terus } \\
\text { menerus }\end{array}$ & 78,84 & 21,16 & 87,50 & 12,50 \\
\hline 2 & Kaizen & 80,76 & 19,24 & 94,79 & 5,21 \\
\hline 3 & Perubahan kultur & 90,00 & 10,00 & 95,70 & 4,30 \\
\hline 4 & Organisasi terbalik & 92,30 & 7,70 & 98,75 & 1,25 \\
\hline 5 & $\begin{array}{l}\text { Menjaga hubungan } \\
\text { dengan pelanggan }\end{array}$ & 80,76 & 18,24 & 94,53 & 5,47 \\
\hline 6 & $\begin{array}{l}\text { Kolega sebagai } \\
\text { pelanggan }\end{array}$ & 90,00 & 10,00 & 92,50 & 7,50 \\
\hline 7 & Pemasaran internal & 88,46 & 11,54 & 93,75 & 6,25 \\
\hline 8 & Profesionalisme & 90,00 & 10,00 & 94,79 & 5,21 \\
\hline \multirow[t]{4}{*}{9} & Mutu pembelajaran & 98,46 & 1,54 & 97,50 & 2,50 \\
\hline & Jumlah & 789,58 & - & 849,81 & - \\
\hline & Rata-rata & 87,73 & 12,26 & 94,42 & 5,57 \\
\hline & Standar deviasi & 6,40 & 6,40 & 3,20 & 3,20 \\
\hline
\end{tabular}

Manajemen SD Negeri Karangrejek II telah mengaplikasikan TQM sebagai sebuah pendekatan praktis, namun strategis sebagaimana dikemukakan dalam teorinya Sallis (2002, p.5) “...is a practical but strategic approach to running an organization that focuses on the needs of its customers and clients". Dalam pandangan SD Karangrejek II supaya organisasi atau lembaga pendidikannya mampu bertahan maka harus 
memfokuskan diri pada pelayanan pelanggan berupa pembelajaran yang baik. Namun hasil ini tidak didukung atau terdapat kontradiksi di mana aspek menjaga hubungan dengan pelanggan justru mendapatkan skor terendah.

Mutu pembelajaran mencapai skor tertinggi di SD Negeri Karangrejek II didasari oleh aspek historis keberadaan sekolah ini. Sebagai lembaga yang berusia hampir $1 / 2$ abad (SD Negeri Karangrejek II berdiri 1 Agustus 1964) tentu memiliki pengalaman dalam pengelolaan pembelajaran. SD Negeri Karangrejek II juga merupakan sekolah dasar dengan status SDSN angkatan pertama. Katagorisasi SDSN di Dinas Pendidikan, Pemuda, dan Olahraga Kabupaten Gunungkidul dimulai sejak tahun 2008. SD Karangrejek II merupakan satu-satu sekolah dari Kecamatan Wonosari yang mampu meraih predikat SDSN bersama 6 SD lain, yaitu: SD semanu III, SD Wiladeg, Karangmojo, SD Jetis I, Saptosari, SD Patuk I, SD Paliyan II, dan SD Bintaos, Tepus.

Aspek lain yang mendukung menempatkan mutu pembelajaran sebagai aspek tertinggi karena para guru menyadari bahwa pembelajaran yang bermutu adalah pembelajaran yang memberikan kesempatan pada murid untuk berinteraksi. Hal ini sejalan dengan kerangka manajemen pengembangan mutu terpadu, bahwa usaha pendidikan tidak lain adalah merupakan usaha "jasa" yang memberikan pelayanan kepada pelanggannya, yaitu mereka yang belajar dalam lembaga pendidikan tersebut. Mereka yang belajar tersebut (pelajar/ murid/peserta belajar) yang biasa disebut klien/pelanggan primer (primary external customers) harus mendapatkan pelayanan pembelajaran yang optimal dan maksimal.

SD Muhammadiyah Al Mujahidin aspek organisasi terbalik menjadi aspek dengan rata-rata tertinggi. Hal ini terjadi karena SD Muhammadiyah Al Mujahidin menempatkan siswa sebagai fokus utama pelayanan, mengutamakan kepuasan pelanggan dan memberikan pelayanan total kepada pelanggan (siswa dan orang tua murid). Di samping itu, manajemen pun- cak SD Muhammadiyah Al Mujahidin memberikan dukungan penuh kepada guru untuk memberikan kepuasan siswa dalam pembelajaran. Manajemen puncak juga memberikan kewenangan kepada guru untuk mencurahkan gagasan dan ide bagi pengembangan pembelajaran di kelas. Skor aspek menjaga hubungan dengan pelanggan menyumbang rata-rata sebesar 94,53 .

Fungsi-fungsi manajemen telah berjalan dengan baik di SD Muhammadiyah Al Mujahidin. Hal ini terbukti, di samping organisasi terbalik berada di skor puncak, aspek kaizen dan perubahan kultur menjadi 2 aspek di atas rata-rata, dengan skor masing-masing 94,79 dan 95,70.

Hasil penelitian yang menunjukkan SD Negeri Karangrejek II aspek mutu pembelajaran merupakan aspek dengan skor tertinggi sedangkan pada SD Muhammadiyah Al Mujahidin aspek yang memperoleh skor tertinggi organisasi terbalik menggambarkan karakteristik organisasi lembaga pendidikan tersebut. SD Karangrejek II sebagai lembaga pendidikan yang berusia cukup akan mempertahankan cara-cara tradisional dalam mempertahankan diri pada persaingan. Kondisi SD Karangrejek II ini sesuai dengan pendapatnya Naidu, Babu \& Rajendra yang memandang lembaga akan mempertahankan ciri-ciri tradisional untuk bertahan di dalam kompetisi (an enhancement to the traditional way of doing business. It is a proven technique to guarantee survival in world-class competition). Hanya dengan mengubah tindakan dari manajemen akan kultur dan tindakan, maka keseluruhan organisasi akan berubah (Only by changing the actions of management will the culture and actions of an entire organization be transformed (Naidu, Babu \& Rajendra, 2006, p.27).

Standar deviasi data SD Karangrejek II sebesar 6,41 yang menandakan data penelitian menyebar dan memiliki kecenderungan setiap data berbeda satu sama lain. Hal ini sesuai dengan kondisi personalia guru/karyawan dengan latar belakang pendidikan dan usia yang beragam. Berbeda dengan standar deviasi SD Muhammadiyah Al Mujahidin yang sebesar 3,20 me- 
nandakan data pengamatan mendekati homogen dan memiliki kecenderungan semua data memiliki nilai yang mendekati identik. Guru/karyawan SD Muhammadiyah Al Mujahidin yang relatif homogen dari sisi usia dan latar belakang pendidikan menjadi faktor penyumbang standar deviasi data tersebut.

Temuan yang menarik dari penelitian ini adalah aspek perbaikan terus menerus menjadi aspek dengan skor terendah di kedua tempat penelitian. Apabila dihubungkan dengan teorinya Sallis (2012, p.73) bahwa Total Quality Management adalah filosofi tentang perbaikan secara terus menerus. Perbaikan terus menerus ini akan menghasilkan seperangkat alat praktis untuk institusi pendidikan dalam memenuhi kebutuhan, keinginan, dan harapan para pelanggannya, saat ini dan untuk masa yang akan datang.

Perbaikan terus-menerus (continuous improvement) dalam pandangan Sallis (2002, p.25) merupakan pendekatan stategik ditujukan untuk memenuhi kebutuhan pelanggan (strategic approach to running an organization that focuses on the needs of its customers and clients). Sebagai sebuah pendekatan strategik, perbaikan terus-menerus membutuhkan fokus organisasi sekolah untuk mempertahankan perbaikan tersebut dalam jangka waktu yang lama menuju perbaikan kualitas (an institution's focus away from short-term expediency to the longterm quality improvement).

Perbaikan berlanjut (continual improvement) dari kinerja organisasi secara keseluruhan harus menjadi tujuan tetap dari organisasi. Organisasi yang berhenti memperbaiki diri akan tertinggal dengan perkembangan jaman, dan berpotensi ditinggalkan oleh pelanggan. Perbaikan berkesinambungan didefinisikan sebagai suatu proses yang berfokus pada upaya terusmenerus meningkatkan efektivitas dan/ atau efisiensi organisasi untuk memenuhi kebijakan dan tujuan dari organisasi itu (constant innovation, improvement and change are stressed, and those institutions that practise it lock into a cycle of continuous improvement). Perbaikan berkesinambung membutuhkan langkah-langkah konsolidasi yang progresif, merespon perkembangan kebutuhan dan ekspektasi pelanggan sehingga akan menjamin suatu evolusi dinamis dari sistem manajemen mutu. TQM dapat dipahami sebagai filosofi perbaikan tanpa henti hingga tujuan organisasi dapat tercapai. Untuk menumbuhkan budaya perbaikan terus-menerus manajemen puncak harus mempercayai dan memberikan kewenangan kepada seluruh staf dan bawahan (to create a continuous improvement culture, managers have to trust their staff and to delegate decisions).

Latar belakang pelanggan yang terbatas menyulitkan SD Negeri Karangrejek II dalam melakukan perbaikan terus-menerus (continuous improvement). Hal ini didukung data penelitian aspek menjaga hubungan dengan pelanggan merupakan aspek di bawah rata-rata, sedangkan aspek kolega sebagai pelanggan dan pemasaran internal yang merupakan katagori pelanggan internal mendapatkan skor di atas rata-rata.

Kondisi tersebut juga terjadi pada SD Muhammadiyah Al Mujahidin, aspek-aspek organisasi terbalik, perubahan kultur, dan menjaga hubungan dengan pelanggan merupakan aspek di atas rata-rata. Sementara aspek-aspek dalam katagori pelanggan internal (kolega sebagai pelanggan dan pemasaran internal) merupakan aspek yang berada di bawah rata-rata. Hal ini menunjukkan bahwa SD Muhammadiyah Al Mujahidin memiliki organisasi yang solid dan kuat dengan berpedoman aturan dan komitmen yang dibuat. Keputusan yang diambil tidak didasarkan pada kebijakan yang bersifat subyektifitas. Proses seleksi siswa baru dengan standar yang tinggi dan prosedur yang tetap menjadi penyumbang tingginya skor organisasi terbalik dan rendahnya kolega sebagai pelanggan dan pemasaran internal.

\section{Simpulan dan Saran}

Simpulan

Berdasarkan hasil penelitian yang telah dilaksanakan tentang implementasi 
TQM pada Sekolah Dasar Negeri Karangrejek II dan SD Muhammadiyah Al Mujahidin, Kecamatan Wonosari, Kabupaten Gunungkidul dapat disimpulkan sebagai berikut: (1) implementasi Total Quality Management (TQM) di SD Negeri Karangrejek II skor capaiam rata-rata sebesar sebesar $87,73 \%$ rata-rata kesenjangan (descrepancy) sebesar $12,26 \%$ dengan standar deviasi sebesar 6,40. Aspek dengan capaian skor tertinggi adalah mutu pembelajaran dengan total rata-rata sebesar $98,46 \%$, tingkat kesenjangan 1,54\%. Sedangkan aspek terendah adalah Perbaikan terus-menerus dengan rata-rata $78,84 \%$. Rata-rata implementasi Total Quality Management (TQM) di SD Muhammadiyah Al Mujahidin sebesar 94,42\% dengan tingkat kesenjangan sebesar 5,57\%, dan standar deviasi 3,20. Aspek dengan capaian skor rata-rata tertinggi adalah organisasi terbalik dengan rata-rata $98,75 \%$, dan aspek terendah adalah perbaikan terus-menerus dengan rata-rata sebesar 87,50\%; (2) implementasi Total Quality Management (TQM) SD Muhammadiyah Al Mujahidin lebih tinggi dibandingkan dengan SD Karangrejek II, dengan rata-rata $94,42 \%$ berbanding $87,73 \%$ dan standar deviasi 3,20 berbanding 6,40. Di kedua obyek penelitian masing-masing terdapat 6 aspek dengan skor capaian di atas rata-rata dan 3 aspek dengan skor capaian di bawah rata-rata. Aspek mutu pembelajaran menjadi aspek yang selalu di atas rata-rata di SD Negeri Karangrejek II dan SD Muhammadiyah Al Mujahidin; (3) aspek-aspek yang perlu mendapat perbaikan untuk ditingkatkan supaya mendekati standar dalam Implementasi Total Quality Management (TQM) di SD Negeri Karangrejek II dan SD Muhammadiyah Al Mujahidin adalah aspek perbaikan terus-menerus. Aspek ini mendapatkan skor capaian terendah di kedua obyek penelitian. Aspek lain yang perlu ditingkat di SD Karangrejek II adalah aspek menjaga hubungan dengan pelanggan, dan Kaizen. Sedangan di SD Muhammadiyah Al Mujahidin, selain perbaikan terus menerus, aspek lain yang perlu mendapatkan perhatian untuk ditingkat- kan adalah aspek pemasaran internal dan kolega sebagai pelanggan.

Saran

\section{Bagi Kepala Sekolah}

a. Guru dan karyawan perlu diberikan motivasi berkesinambungan yang sistematis dalam penerapan Total Quality Management (TQM) di sekolah.

b. SD Negeri Karangrejek II, aspek mutu pembelajaran merupakan skor capaian tertinggi. Hal ini menunjukkan pelaksanaan proses belajar mengajar telah berlangsung dengan baik, sehingga perlu dipertahankan dan ditingkatkan.

c. SD Muhammadiyah Al Mujahidin, aspek organisasi terbalik merupakan skor capaian tertinggi. Hal ini menunjukkan fungsi-fungsi manajemen di telah berjalan dengan baik, kepala sekolah atau manajemen senior dan menengah telah mampu memberi dukungan dan wewenang pada staf dan siswa, sehingga perlu dipertahankan.

d. Total Quality Management (TQM) adalah sebuah pendekatan sistematis dengan penekanan pada kepuasan pelanggan. Sehingga sekolah perlu menyusun program penjaminan mutu yang bertujuan pemuasan pelanggan, dan bukan sekedar pemenuhan dokumen mutu.

\section{Bagi Dinas Pendidikan dan LPMP}

a. Para calon kepala sekolah saat Diklat, hendaknya dibekali strategi Total Quality Management (TQM) yang praktis dan mudah diterapkan di sekolah.

b. Lembaga Penjaminan Mutu Pendidikan (LPMP) supaya menerapkan Total Quality Management (TQM) di sekolah dasar yang betul-betul menyentuh substansi peningkatan mutu, tidak hanya sekedar penerapan dokumen-dokumen mutu.

\section{Bagi peneliti selanjutnya}

Hasil penelitian ini diharapkan bisa membantu para peneliti selanjutnya terutama yang akan meneliti tentang Total Quality Management (TQM) di sekolah dasar. 


\section{Daftar Pustaka}

Depdiknas. (2001). Manajemen peningkatan mutu berbasis sekolah, buku 1 konsep dan pelaksanaan

Depdiknas. (2005). Peraturan Menteri Pendidikan Nasional Nomor 63 Tahun 2009, tentang Sistem Penjaminan Mutu Pendidikan.

Fernandes, H.J.X. (1984). Evaluation of educational programs, Jakarta: National Education Planning, Evaluation and Curriculum Development

Lunenburg, F.C. (2010). Total quality management applied to schools. Diakses tanggal 5 Mei 2013 dari http:// nationalforum.com/total-qualitymanagement-appplied-toschools.htm
Naidu, N.V.R, Babu, K.M \& Rajendra, G. (2006). Total quality management. New Delhi: New Age International (P) Limited Publisher.

Patton, M.Q. (2002). Qualitative evaluation and research methods. ( $3^{\text {rd }}$ ed). California: Sage Publications.

Sallis, E. (2002). Total quality management in education $\left(3^{\text {rd }}\right.$ ed). London: Kogan Page Limited.

Sallis, E. (2012). Total quality management in education. (Terjemahan Ahmad Ali Riyadi). Yogyakarta: IRCiSoD

Sharma, R.C. (2002). Total quality management in education. Diakses tanggal 15 Mei 2013 dari http://tojde. Anadolu.edu.tr/todje7/reviews/Rames h.htm 